Article

\title{
Antibacterial and Antifungal Activities of Proteins Extracted from Seven Different Snails
}

\author{
Selvakumari Ulagesan ${ }^{1}$ and Hak Jun Kim ${ }^{2, *}$ \\ 1 Institute of Marine Biotechnology, Pukyong National University, Busan 48513, Korea; ula.selva@gmail.com \\ 2 Department of Chemistry, Pukyong National University, Busan 48513, Korea \\ * Correspondence: kimhj@pknu.ac.kr; Tel.: +82-51-629-5587
}

Received: 19 July 2018; Accepted: 11 August 2018; Published: 13 August 2018

\begin{abstract}
Snails have been used both as a food and as a treatment for a variety of medicinal conditions. In this study, seven different snail proteins were evaluated for their antimicrobial activity. Fresh water and land snails of seven different live species were collected and identified. Crude proteins were extracted from seven different snails. The extracted proteins were estimated using Bradford's method and snail proteins were displayed using a sodium dodecyl sulfate-polyacrylamide gel electrophoresis (SDS-PAGE) analysis. The seven different snail proteins were evaluated for their antimicrobial activity against various pathogenic bacterial and fungal cultures by agar well diffusion method and MIC (Minimum Inhibitory Concentration). One of the most active, crude proteins was from land snail Cryptozona bistrialis and its protein was capable of completely inhibiting the development of pathogenic bacterial and fungal cultures. This study shows that the land snail C. bistrialis proteins could be used as an antibiotic in biomedical research.
\end{abstract}

Keywords: antibacterial activity; antifungal activity; snail; minimum inhibitory concentration

\section{Introduction}

Mollusks are an abundant and significant group in the trophic chain of the animal kingdom. Among mollusks, gastropods including snails and slugs, represent the most abundant class. Snails in particular are successful animals from an evolutionary point of view, having survived extreme environmental conditions for more than 600 million years, due to their capacity to adapt to different environments and to reach dry land [1]. This indicates that snails have some special adaptive proteins with which they are able to survive in their environment. For centuries snails have been used as a food and as treatment for a variety of medicinal conditions. Generally, few extensive investigations have been made of the antimicrobial proteins of mollusks groups although whole body homogenates of some marine mollusks have been reported to contain a variety of antimicrobial and antioxidant compounds.

Nowadays antimicrobial resistance developed by bacterial and fungal pathogens is one of the major health problems that affect all countries [2]. Therefore, the development of newer antimicrobial therapies that diminishes this resistance is urgent. Mollusks are said to be a pharmacologically significant outlet. The highly protein-rich and delicious Molluscan meat is in increasing demand throughout the world. Thousands of bioactive compounds have been discovered in mollusks. They are peptides, sterols, terpenes, polypropinate, nitrogenous compounds, fatty acid derivatives, miscellaneous compounds and alkaloids [3]. Many bioactive compounds have been investigated predominantly for their antimicrobial, cytotoxic, anti-tumor and anti-inflammatory, antileukemic, antineoplastic and antiviral properties of mollusks [4-7]. Antibacterial and antiviral activities have been previously reported in the hemolymph of several molluscan species such as sea hares, sea slung, oysters, and mussels [8-14]. Over recent years, numerous studies on snail mucus composition have clarified many aspects of its properties, although much remains to be investigated on its antibacterial 
activity. Recently, several studies carried out on snail secretion composition have confirmed that the Helix aspersa mucus contains a great number of natural substances with beneficial and therapeutic properties for human skin, such as allantoin and glycolic acid [15]. However, there is no extensive report on the antimicrobial activity of terrestrial snails in India. Considering recent studies of developing food protein-derived bioactive peptides as an alternative to synthetic pharmaceuticals for the treatment of various diseases, it is worth evaluating the antibacterial and antifungal activities of proteins extracted from these animals. In this study, we aimed toextract proteins from seven snail species and evaluate the antibacterial and antifungal activities of proteins against pathogenic bacteria and fungi for potential biomedical application.

\section{Materials and Methods}

\subsection{Sample Collection and Identification}

Freshwater and land snails of seven different live species were collected from various regions such as Porur Lake, Porur fish market and Thirumazhisai agricultural field, Chennai, Tamil Nadu, India. The seven mollusks used in the present study were Achatina fulica (Bowdich, 1822), Cryptozona bistrialis (Beck, 1837), Pila globosa (Swainson, 1822), Pila virens (Lamarck, 1822), Bellamya dissimilis (Mueller, 1774), Bithynia (Digoniostoma) pulchella (Benson, 1836), and Melanoides tuberculata (Muller, 1774). The snail samples were deposited into the National repository of Zoological Survey of India, Southern Regional Centre, as National Zoological Collections, the proper registration numbers were allotted along with all the collection details.

\subsection{Extraction of Proteins from Seven Snail Species}

The snails were washed with distilled water, the shells were broken and the soft bodies were separated and stored at $-20{ }^{\circ} \mathrm{C}$ prior to use. Soft bodies of the snails were homogenized separately in a solution containing $10 \%$ ice cold acetic acid 1:3 w/v in a blender ( 1 gm snail tissue and $3 \mathrm{~mL}$ of $10 \%$ acetic acid). The homogenate was centrifuged at $10,000 \times g$ for $30 \mathrm{~min}$ at $4{ }^{\circ} \mathrm{C}$. Soluble proteins were precipitated with ammonium sulfate $\left(\mathrm{NH}_{4}\right)_{2} \mathrm{SO}_{4}$ at $100 \%$ saturation with constant stirring for $1 \mathrm{~h}$ at $4{ }^{\circ} \mathrm{C}$. After centrifugation at $10,000 \times \mathrm{g}$ for $30 \mathrm{~min}$ at $4{ }^{\circ} \mathrm{C}$, the precipitate was suspended in $10 \mathrm{mM}$ Tris- $\mathrm{HCl}$ buffer, $\mathrm{pH} 7.0$ and was further desalted using dialysis membrane [16]. The extracted proteins were stored at $4{ }^{\circ} \mathrm{C}$. The extracted protein concentrations were estimated using the Bradford method [17], with bovine serum albumin (BSA) as a standard. The seven snail proteins were visualized by $12 \%$ SDS-PAGE [18] with the molecular weight marker ranging from $97 \mathrm{kDa}$ to $6.5 \mathrm{kDa}$.

\subsection{Antibacterial and Antifungal Activity Assay}

Antimicrobial activity and minimum inhibitory concentration for the proteins from seven different snails were assessed against 6 human pathogenic bacterial strains and 4 pathogenic fungal strains. The pathogenic bacteria were Staphylococcus aureus, Micrococcus luteus, Pseudomonas aeruginosa, Proteus vulgaris, Serratia marcescens and Hafnia alvei; the pathogenic fungal strains were Candida albicans, Aspergillus fumigatus, Penicillium chrysogenum and Mucor racemosus. These pathogenic cultures were obtained from the King Institute of Preventive Medicine, Guindy, Chennai, Tamil Nadu, India, and were periodically subcultured and maintained in a respective medium at $4{ }^{\circ} \mathrm{C}$. Active cultures for experiments were prepared by transferring a loop full of culture from the stock cultures to test tubes of Luria Bertani (LB) broth for bacteria, and Potato Dextrose (PD) broth for fungi, and were incubated for $24 \mathrm{~h}$ at $37^{\circ} \mathrm{C}$. Antibacterial and antifungal activity of the proteins from the seven different snails was determined by the agar well diffusion method [19]. The nutrient agar plates were swabbed with the respective $24 \mathrm{~h}$ broth culture of organisms and kept for $15 \mathrm{~min}$ in a laminar chamber for absorption of cultures. Wells were made in agar plates using a sterile cork borer of $5 \mathrm{~mm}$. The extracted protein of various concentrations, such as 25,50 , and $100 \mu \mathrm{g} / \mathrm{mL}$, were prepared and $20 \mu \mathrm{L}$ of respective concentrations were added to each well. Distilled water was used as the negative control and 
chloramphenicol $(100 \mu \mathrm{g} / \mathrm{mL})$ used as positive control for bacteria and Amphotericin-B $(100 \mu \mathrm{g} / \mathrm{mL})$ used as positive control for fungi. The plates were incubated at $37^{\circ} \mathrm{C}$ for $24 \mathrm{~h}$. The diameters of the zone of inhibition were measured in millimeter by using the antibiotic zone measuring scale.

The minimum inhibitory concentration (MIC) was determined by the micro dilution method [20] by using liquid nutrient broth with different concentrations of proteins from seven different snails. A total of $3.6 \mathrm{~mL}$ of sterilized nutrient broth was poured into a sterilized test tube. Different concentrations of protein, such as $3.25,6.5,12.2,25,50$ and $100 \mu \mathrm{g} / \mathrm{mL}$, were added to the nutrient broth, to all the test tubes, and $0.4 \mathrm{~mL}$ of bacterial suspension and fungal suspension was added separately; the tubes were then incubated at $37^{\circ} \mathrm{C}$ overnight. In the negative control, the nutrient media was inoculated with microbes without a protein sample $(3.6 \mathrm{~mL}$ nutrient broth added with $0.4 \mathrm{~mL}$ bacteria or fungal culture) and the positive control contains antibiotics by replacing the protein (3.6 mL nutrient broth $+0.4 \mathrm{~mL}$ bacterial culture + chloramphenicol or Amphotericin-B $25 \mu \mathrm{g} / \mathrm{mL}$ ). The growth was observed and the optical density was read at $595 \mathrm{~nm}$ spectrophotometrically for the development of turbidity. MIC was determined by the lowest concentration of sample that inhibited the development of turbidity.

\subsection{Statistical Analysis}

All analyses were carried out in triplicate, and results are reported as the mean \pm standard deviation (SD). Significant differences were analyzed by one-way analysis of variance (ANOVA). Differences at $p<0.05$ were considered significant.

\section{Results}

\subsection{Animals and Protein Extraction}

The snails were identified with the registration numbers in Figure 1. Their protein concentrations were measured using the Bradford method. The protein concentration extracted from A. fulica, C. bistrialis, P. globose, P. virens, B. dissimilis, B. pulchella, and M. tuberculata was about 2.75, 2.2, 2.5, 2.4, $1.2,1.02$, and $1.1 \mathrm{mg} / \mathrm{mL}$, respectively. The protein profile was shown in Figure 2.

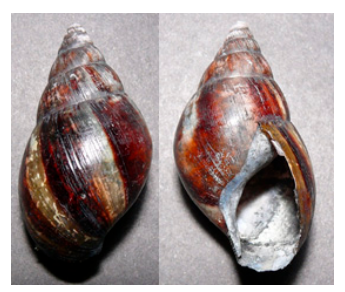

(a)

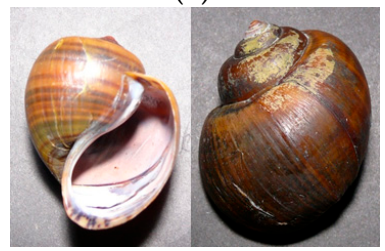

(d)

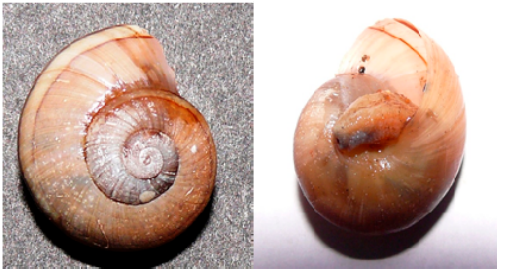

(b)

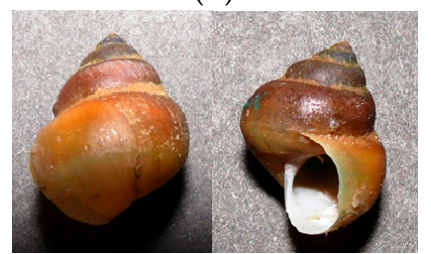

(e)

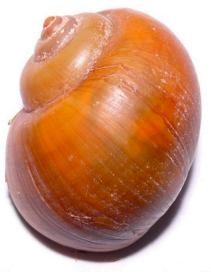

(c)

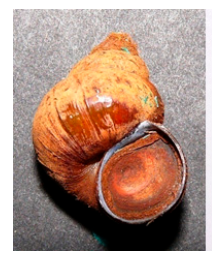

(f)
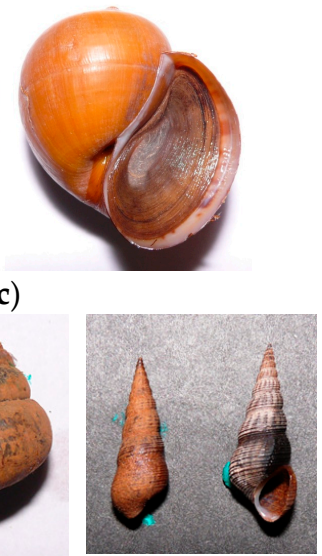

(g)

Figure 1. Dorsal (left) and ventral (right) images of seven snail species used in this study with their registration number in parenthesis. (a) Achatina fulica (LM-550), (b) Cryptozona bistrialis (LM-551), (c) Pila globose (LM-552), (d) Pila virens (LM-553), (e) Bellamya dissimilis (LM-554), (f) Bithynia (Digoniostoma) pulchella (LM-555), and (g) Melanoides tuberculate (LM-556). 


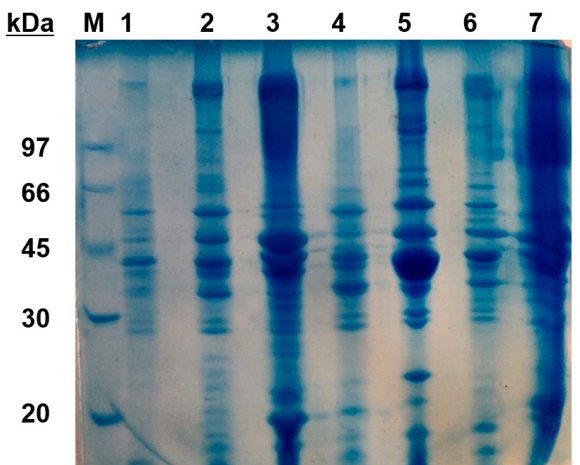

Figure 2. A $12 \%$ SDS-PAGE analysis of protein extracts from seven different snail species. Lane $\mathrm{M}$, medium-range protein molecular weight markers (labelled in kDa); lane 1, Achatina fulica; lane 2, Cryptozona bistrialis; lane 3, Pila globosa; lane 4, Pila virens; lane 5, Bellamya dissimilis; lane 6, Bithynia (Digoniostoma) pulchella; lane 7, Melanoides tuberculata.

\subsection{Antibacterial and Antifungal Activities and MIC}

The antimicrobial activity and minimum inhibitory concentration of seven different snail protein was performed and tabulated in Tables 1-4. In the investigation of Anand and Patterson Edward (2002) [4] on the antibacterial activities of ethanol extracts of gastropod Babylonia spirata and Turbo brunneus, they observed highest activity against E. coli, K. pneumoniae, P. vulgaris and S. typhi. Antibacterial activity was evaluated for seven different snail proteins against various pathogenic cultures. Chloramphenicol $(100 \mu \mathrm{g} / \mathrm{mL})$ was used as a positive control and it showed a maximum $25 \mathrm{~mm}$ zone of inhibition in tested pathogens. The snail A. fulica protein in high concentration $(100 \mu \mathrm{g} / \mathrm{mL})$ has antibacterial activity but the land snail C. bistrialis protein showed the maximum zone of inhibition in at low concentration $(25 \mu \mathrm{g} / \mathrm{mL})$ (Figure 3). The snail P. globosa protein showed activity only against $S$. aureus. The remaining snail proteins such as $P$. virens, B. dissimilis, B. (Digoniostoma) pulchella and M. tuberculata did not show activity in antibacterial and MIC against any of the selected bacterial cultures. In antifungal activity the snail $C$. bistrialis protein also showed potential activity against $C$. albicans, $P$. chrysogenum, A. fumigatus, $M$. racemosus, as compared to other snail proteins. Antifungal and MIC results also showed that the land snail C. bistrialis protein inhibits the microbial growth at low concentration (Figure 3).

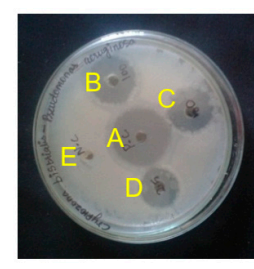

Pseudomonas aeruginosa

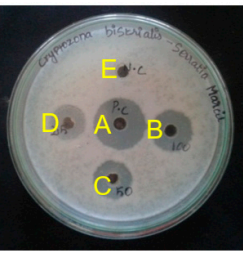

Serratia marcescens

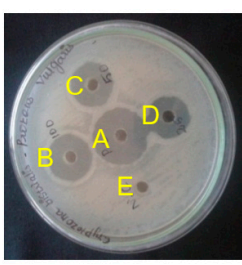

Proteus vulgaris

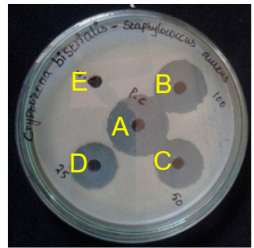

Staphylococcus aureus

(a)

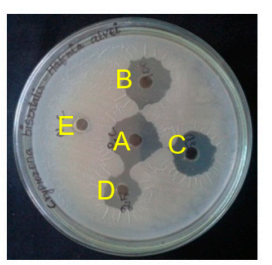

Hafnia alvei

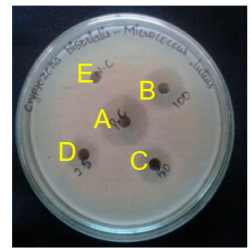

Micrococcus luteus

Figure 3. Cont. 


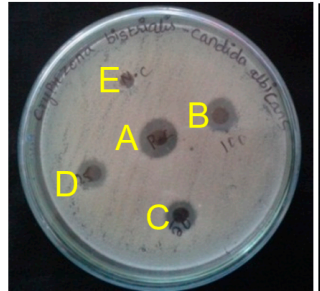

Candida albicans

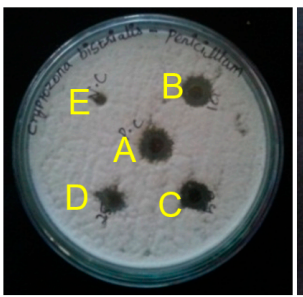

Penicillium chrysogenum Aspergillus fumigatus

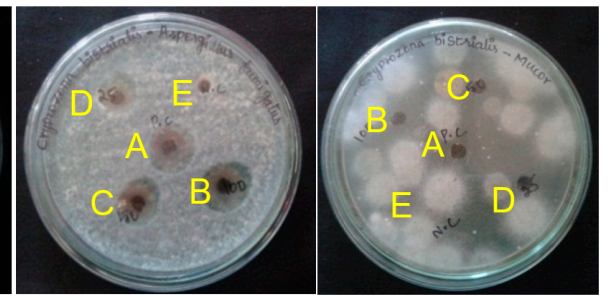

Mucor racemosus

(b)

Figure 3. Antibacterial (a) and antifungal (b) activities of protein extract from Cryptozona bistrialis by Agar well diffusion method. In (a), A, positive control, Chloramphenicol (100 $\mu \mathrm{g} / \mathrm{mL}) ; \mathrm{B}, 100 \mu \mathrm{g} / \mathrm{mL}$; , $50 \mu \mathrm{g} / \mathrm{mL} ; \mathrm{D}, 25 \mu \mathrm{g} / \mathrm{mL}$ of protein extract; E, negative control. In (b) A, positive control, Amphotericin-B $(100 \mu \mathrm{g} / \mathrm{mL}) ; \mathrm{B}, 100 \mu \mathrm{g} / \mathrm{mL} ; \mathrm{C}, 50 \mu \mathrm{g} / \mathrm{mL} ; \mathrm{D}, 25 \mu \mathrm{g} / \mathrm{mL}$ of protein extract; E, negative control.

Table 1. Antibacterial activity of seven different snail proteins using agar well diffusion method.

\begin{tabular}{|c|c|c|c|c|c|c|}
\hline \multirow{2}{*}{ Snails } & \multirow{2}{*}{ Micro-Organisms } & \multicolumn{5}{|c|}{ Zone of Inhibition in $\mathrm{mm}$} \\
\hline & & $25 \mu \mathrm{g} / \mathrm{mL}$ & $50 \mu \mathrm{g} / \mathrm{mL}$ & $100 \mu \mathrm{g} / \mathrm{mL}$ & N.C & Chloramphenicol $100 \mu \mathrm{g} / \mathrm{mL}$ \\
\hline \multirow{6}{*}{ A. fulica } & P. aeruginosa & - & - & - & - & $27.5 \pm 0.5$ \\
\hline & P. vulgaris & - & - & - & - & $22.6 \pm 1.5$ \\
\hline & H. alvei & $6.33 \pm 1.1$ & $8 \pm 2$ & $11 \pm 1$ & - & $22.6 \pm 0.4$ \\
\hline & S. marcescens & $9.33 \pm 1.1$ & $11 \pm 1$ & $14 \pm 2$ & - & $21.33 \pm 1.5$ \\
\hline & S. aureus & $9 \pm 1$ & $11.5 \pm 0.5$ & $15.5 \pm 0.5$ & - & $24.33 \pm 0.5$ \\
\hline & M. luteus & - & - & - & - & $24.66 \pm 0.5$ \\
\hline \multirow{6}{*}{ C. bistrialis } & P. aeruginosa & $11 \pm 1$ & $13.33 \pm 1.5$ & $21.66 \pm 1.15$ & - & $25 \pm 1$ \\
\hline & P. vulgaris & $11.33 \pm 0.4$ & $15.33 \pm 0.5$ & $19 \pm 1$ & - & $25.3 \pm 0.5$ \\
\hline & H. alvei & $11.6 \pm 0.5$ & $15 \pm 1$ & $20 \pm 1$ & - & $22.3 \pm 0.5$ \\
\hline & S. marcescens & $10 \pm 1$ & $14.33 \pm 1.52$ & $19 \pm 1$ & - & $24.33 \pm 0.57$ \\
\hline & S. aureus & $10 \pm 1$ & $11.3 \pm 0.76$ & $14.6 \pm 1.1$ & - & $25 \pm 1$ \\
\hline & M. luteus & $9.5 \pm 1.3$ & $11.5 \pm 1.3$ & $20.6 \pm 1.5$ & - & $25.5 \pm 0.5$ \\
\hline \multirow{6}{*}{ P. globosa } & P. aeruginosa & - & - & - & - & $23.6 \pm 0.57$ \\
\hline & P. vulgaris & - & - & - & - & $24 \pm 1$ \\
\hline & H. alvei & - & - & - & - & $21.3 \pm 0.5$ \\
\hline & S. marcescens & - & - & - & - & $19 \pm 1$ \\
\hline & S. aureus & $8.16 \pm 0.28$ & $10.3 \pm 0.5$ & $15.83 \pm 0.76$ & - & $24 \pm 1$ \\
\hline & M. luteus & - & - & - & - & $17.6 \pm 0.5$ \\
\hline \multirow{6}{*}{ P. virens } & P. aeruginosa & - & - & - & - & $25.6 \pm 0.5$ \\
\hline & P. vulgaris & - & - & - & - & $22.5 \pm 0.5$ \\
\hline & H. alvei & - & - & - & - & $24.66 \pm 0.57$ \\
\hline & S. marcescens & - & - & - & - & $22.5 \pm 0.5$ \\
\hline & S. aureus & - & - & - & - & $24.3 \pm 0.5$ \\
\hline & M. luteus & - & - & - & - & $24 \pm 1$ \\
\hline \multirow{6}{*}{ B. dissimilis } & P. aeruginosa & - & - & - & - & $25.6 \pm 0.57$ \\
\hline & P. vulgaris & - & - & - & - & $20.66 \pm 1.15$ \\
\hline & H. alvei & - & - & - & - & $20.66 \pm 0.57$ \\
\hline & S. marcescens & - & - & - & - & $20 \pm 1$ \\
\hline & S. aureus & - & - & - & - & $24.6 \pm 0.57$ \\
\hline & M. luteus & - & - & - & - & $23 \pm 0.5$ \\
\hline \multirow{6}{*}{ B. pulchella } & P. aeruginosa & - & - & - & - & $24.5 \pm 0.76$ \\
\hline & P. vulgaris & - & - & - & - & $20.3 \pm 0.57$ \\
\hline & H. alvei & - & - & - & - & $19.5 \pm 0.5$ \\
\hline & S. marcescens & - & - & - & - & $19.3 \pm 0.57$ \\
\hline & S. aureus & - & - & - & - & $23.6 \pm 0.5$ \\
\hline & M. luteus & - & - & - & - & $23.6 \pm 0.6$ \\
\hline \multirow{6}{*}{ M. tuberculata } & P. aeruginosa & - & - & - & - & $25.5 \pm 0.5$ \\
\hline & P. vulgaris & - & - & - & - & $23 \pm 1$ \\
\hline & H. alvei & - & - & - & - & $20.5 \pm 0.5$ \\
\hline & S. marcescens & - & - & - & - & $22 \pm 1$ \\
\hline & S. aureus & - & - & - & - & $23.3 \pm 0.5$ \\
\hline & M. luteus & - & - & - & - & $24.76 \pm 0.6$ \\
\hline
\end{tabular}


Table 2. Minimum inhibitory concentration of seven different snail proteins against bacteria.

\begin{tabular}{ccccccc}
\hline Organisms & P. aeruginosa & P. vulgaris & H. alvei & S. marcescens & S. aureus & M. luteus \\
\hline A. fulica & $100^{1}\left(16.4^{2}\right)$ & ND. & $100^{1}\left(9.2^{2}\right)$ & $100^{1}\left(16.5^{2}\right)$ & $100^{1}\left(12.8^{2}\right)$ & ND. \\
C. bistrialis & $12.5^{1}\left(86.6^{2}\right)$ & $12.5^{1}\left(88.2^{2}\right)$ & $25^{1}\left(86.5^{2}\right)$ & $25^{1}\left(86.8^{2}\right)$ & $12.5^{1}\left(90.9^{2}\right)$ & $25^{1}\left(70.82^{2}\right)$ \\
P. globosa & $50^{1}\left(14.8^{2}\right)$ & ND. & ND. & ND. & $100^{1}\left(10.02^{2}\right)$ & ND. \\
P. virens & $100^{1}\left(11.38^{2}\right)$ & ND. & ND. & ND. & ND. & ND. \\
B. dissimilis & ND. & ND. & ND. & ND. & ND. & ND. \\
B. pulchella & ND. & ND. & ND. & ND. & ND. & ND. \\
M. tuberculata & ND. & ND. & ND. & ND. & ND. & ND. \\
\hline
\end{tabular}

ND. Not determined: no activity was detected at the highest concentration tested; ${ }^{1}$ Protein concentration $(\mu \mathrm{g} / \mathrm{mL})$ which inhibit the microbial growth; ${ }^{2}$ LC50 values are expressed as the concentration that causes $50 \%$ decrease in optical density of microorganism suspension.

Table 3. Antifungal activity of seven different snail proteins.

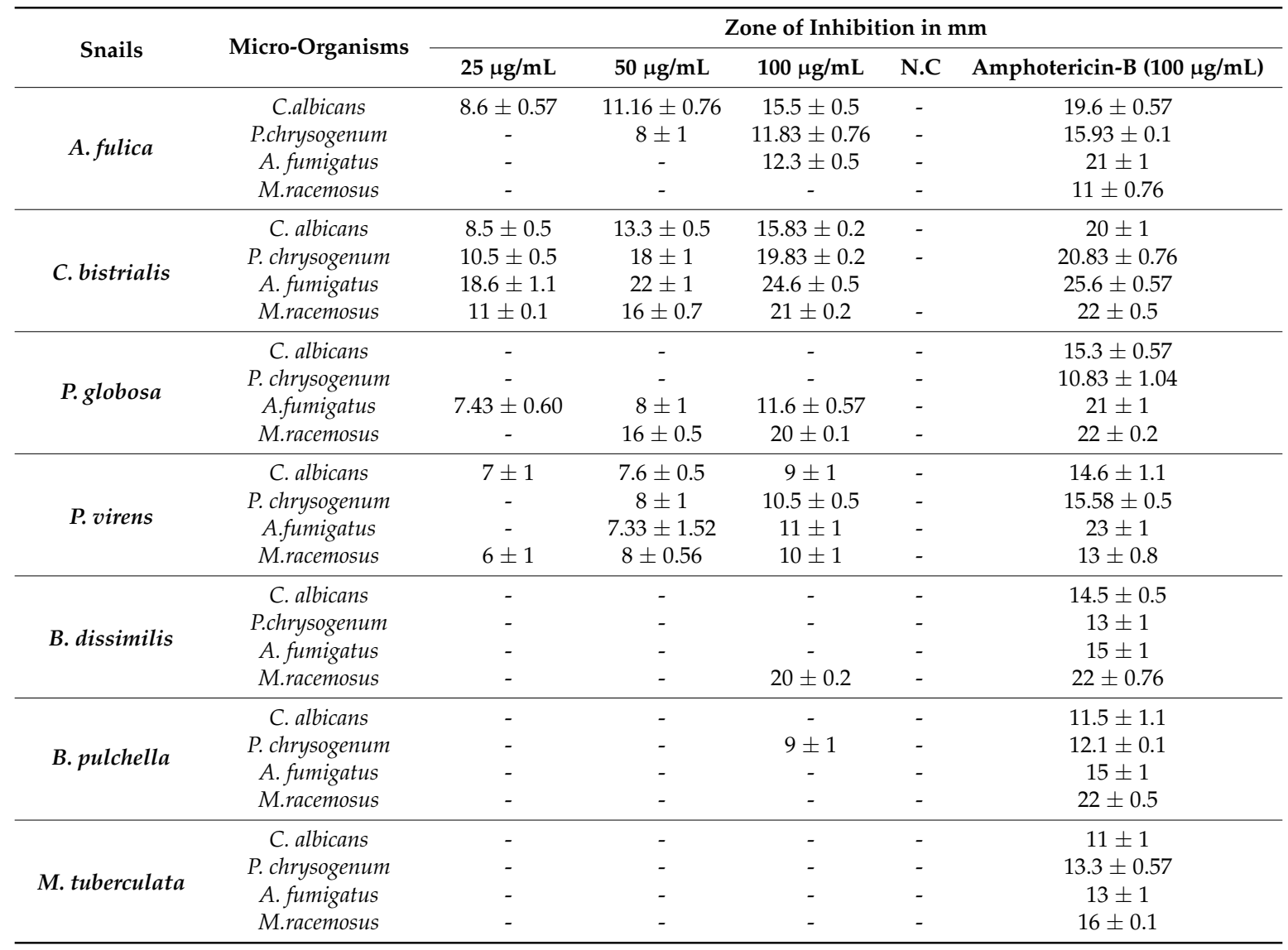

Table 4. Minimum inhibitory concentration of seven different snail proteins against fungi.

\begin{tabular}{ccccc}
\hline Organisms & C. albicans & P. chrysogenum & A. fumigatus & M. racemosus \\
\hline A. fulica & $100^{1}\left(10.4^{2}\right)$ & $100^{1}\left(12.8^{2}\right)$ & ND. & ND. \\
C. bistrialis & $50^{1}\left(74.6^{2}\right)$ & $50^{1}\left(80.1^{2}\right)$ & $25^{1}\left(66.82^{2}\right)$ & $25^{1}\left(70.8^{2}\right)$ \\
P. globosa & $100^{1}\left(11.3^{2}\right)$ & $100^{1}\left(15.12^{2}\right)$ & ND. & ND. \\
P. virens & $100^{1}\left(17.18^{2}\right)$ & ND. & ND. & ND. \\
B. dissimilis & ND. & ND. & ND. & ND. \\
B. pulchella & ND. & ND. & ND. & ND. \\
M. tuberculata & ND. & ND. & ND. & ND. \\
\hline
\end{tabular}

ND: Not determined: no activity was detected at the highest concentration tested; ${ }^{1}$ Protein concentration $(\mu \mathrm{g} / \mathrm{mL})$ which inhibit the microbial growth; ${ }^{2}$ LC50 values are expressed as the concentration that causes $50 \%$ decrease in optical density of microorganism suspension. 


\section{Discussion}

In this study, we evaluated the antibacterial and antifungal activities of proteins extracted from seven different snail species. The proteins extracted from the terrestrial snail C. bistrialis showed highest antimicrobial activity at low concentration against tested pathogenic bacterial and fungal cultures compared to other selected snail proteins. The protein extract from C. bistrialis near completely inhibited the development of pathogenic bacterial and fungal cultures. This result indicates that different natural antimicrobial substances are present among snails. The protein extract from the gastropod C. bistrialis especially needs to be investigated further, in order to identify the antibacterial and/or antifungal substances which could serve as a template for developing novel antibiotics for microbial infections. There are a few reports on potent antimicrobial activities of extracts from gastropods [7,16,21-23]. Rajaganapathi et al. (2002) [7] reported the antibacterial activity of gastropods against S. typhi. Lopez et al. (2012) [16] evaluated the antimicrobial activity of the crude extract of Caribbean Sea invertebrates and isolated the bactericidal proteins from the Littoral Mollusk Cenchritis muricatus. One of the most active crude extracts was the marine snail C. muricatus. Sugesh et al. (2013) [21] also screened the antibacterial activity of marine gastropod Hemifusus pugilinus. Gayathri et al. (2014) [24] investigated the antibacterial activity of ethanol extract of the freshwater gastropod P. virens (Lamarck, 1822). Dolashka et al. (2015) [22] evaluated the antimicrobial activities of peptides isolated from the hemolymph of the molluscan garden snail Helix lucorum, which exhibited inhibition effects against S. aureus, S. epidermidis and E. coli. According to Santana et al. (2012) [23], the mucus secretion of Achatina fulica has potential antibacterial, antifungal and wound healing efficacy in Wistar albino rats. Despite previous investigations, antibacterial and antifungal activities of tissue extract from mollusks including snails and slugs have never been suggested extensively. Our results proved that snails are not only an important food source, but also very promising candidates for screening biological activities such as antioxidant, anticancer, antiviral, anti-inflammatory activities.

\section{Conclusions}

In the present work, results indicate the presence of different natural antimicrobial substances in the mollusks. Among the seven different snail proteins, the snail C. bistrialis protein showed the maximum antimicrobial activity against tested pathogenic organisms. Among the seven snail proteins, one of the most active, crude proteins was from the land snail C. bistrialis. It was capable of completely inhibiting the development of pathogenic bacterial and fungal cultures. The results clearly showed that the protein obtained from land snail C. bistrialis act as the bioactive compound against the pathogenic microorganisms. It is promising that the protein extracts from tested gastropod C. bistrialis can be a candidate to be searched for novel antibiotics for microbial infections. Further investigations to purify these active compounds should be considered to clarify their chemical composition.

Author Contributions: Conceptualization, S.U.; Methodology, S.U.; Validation, S.U. and H.J.K.; Formal Analysis, S.U. and H.J.K.; Data Curation, S.U. and H.J.K.; Writing-Original Draft Preparation, S.U.; Writing-Review and Editing, H.J.K.; Visualization, S.U. and H.J.K.; Supervision, H.J.K.; Funding Acquisition, H.J.K.

Funding: This study was supported by the grant from the Korea Institute of Marine Science \& Technology Promotion (KIMST; Project \#20170327), Ministry of Oceans and Fisheries, Republic of Korea.

Acknowledgments: Authors appreciate R. Venkitesan (Zoological Survey of India) for identifying snail species.

Conflicts of Interest: The authors declare no conflict of interest.

\section{References}

1. González, Y.; Tanaka, A.S.; Hirata, I.Y.; del Rivero, M.A.; Oliva, M.L.V.; Araujo, M.S.; Chávez, M.A. Purification and partial characterization of human neutrophil elastase inhibitors from the marine snail Cenchritis muricatus (Mollusca). Comp. Biochem. Physiol. A Mol. Integr. Physiol. 2007, 146, 506-513. [CrossRef] [PubMed]

2. Arias, C.A.; Murray, B.E. Antibiotic-Resistant Bugs in the 21st Century-A Clinical Super-Challenge. N. Engl. J. Med. 2009, 360, 439-443. [CrossRef] [PubMed] 
3. Blunt, J.W.; Copp, B.R.; Hu, W.-P.; Munro, M.H.G.; Northcote, P.T.; Prinsep, M.R. Marine natural products. Nat. Prod. Rep. 2009, 26, 170. [CrossRef] [PubMed]

4. Anand, T.P.; Edward, J.K.P. Antimicrobial activity in the tissue extracts of five species of cowries cypraea spp. (Mollusca: Gastropoda) and an ascidian didemnum psammathodes (Tunicata: Didemnidae). Indian J. Mar. Sci. 2002, 31, 239-242.

5. Kamiya, H.; Muramoto, K.; Goto, R.; Sakai, M.; Endo, Y.; Yamazaki, M. Purification and characterization of an antibacterial and antineoplastic protein secretion of a sea hare, Aplysia juliana. Toxicon 1989, 27, 1269-1277. [CrossRef]

6. Pettit, G.R.; Kamano, Y.; Herald, C.L.; Tuinman, A.A.; Boettner, F.E.; Kizu, H.; Schmidt, J.M.; Baczynskyj, L.; Tomer, K.B.; Bontems, R.J. The isolation and structure of a remarkable marine animal antineoplastic constituent: dolastatin 10. J. Am. Chem. Soc. 1987, 109, 6883-6885. [CrossRef]

7. Rajaganapathi, J.; Thyagarajan, S.P.; Patterson Edward, J.K. Study on cephalopod's ink for anti-retroviral activity. Indian J. Exp. Biol. 2000, 38, 519-520. [PubMed]

8. Mitta, G.; Hubert, F.; Noel, T.; Roch, P. Myticin, a novel cysteine-rich antimicrobial peptide isolated from haemocytes and plasma of the mussel Mytilus galloprovincialis. Eur. J. Biochem. 1999, 265, 71-78. [CrossRef] [PubMed]

9. Nakamura, T.; Furunaka, H.; Miyata, T.; Tokunaga, F.; Muta, T.; Iwanaga, S.; Niwa, M.; Takao, T.; Shimonishi, Y. Tachyplesin, a class of antimicrobial peptide from the hemocytes of the horseshoe crab (Tachypleus tridentatus). Isolation and chemical structure. J. Biol. Chem. 1988, 263, 16709-16713. [PubMed]

10. Zasloff, M. Antimicrobial peptides of multicellular organisms. Nature 2002, 415, 389-395. [CrossRef] [PubMed]

11. Gueguen, Y.; Garnier, J.; Robert, L.; Lefranc, M.P.; Mougenot, I.; de Lorgeril, J.; Janech, M.; Gross, P.S.; Warr, G.W.; Cuthbertson, B.; et al. PenBase, the shrimp antimicrobial peptide penaeidin database: sequence-based classification and recommended nomenclature. Dev. Comp. Immunol. 2006, 30, 283-288. [CrossRef] [PubMed]

12. Olicard, C.; Renault, T.; Torhy, C.; Benmansour, A.; Bourgougnon, N. Putative antiviral activity in hemolymph from adult Pacific oysters, Crassostrea gigas \{UR\} \{-://WOS:000229819900008\}. Antivir. Res. 2005, 66, 147-152. [CrossRef] [PubMed]

13. Roch, P.; Yang, Y.; Toubiana, M.; Aumelas, A. NMR structure of mussel mytilin, and antiviral-antibacterial activities of derived synthetic peptides. Dev. Comp. Immunol. 2008, 32, 227-238. [CrossRef] [PubMed]

14. Kuppusamy, A.; Ulagesan, S. Antimicrobial activity of protein hydrolysate from marine molluscs babylonia spirata (Linnaeus, 1758). J. Appl. Pharm. Sci. 2016, 6. [CrossRef]

15. El Mubarak, M.A.S.; Lamari, F.N.; Kontoyannis, C. Simultaneous determination of allantoin and glycolic acid in snail mucus and cosmetic creams with high performance liquid chromatography and ultraviolet detection. J. Chromatogr. A 2013, 1322, 49-53. [CrossRef] [PubMed]

16. Lopez Abarrategui, C.; Alba, A.; Lima, L.; Neto, S.; Vasconcelos, I.; Oliveira, J.; Dias, S.; Otero, A.; Franco, O. Screening of Antimicrobials from Caribbean Sea Animals and Isolation of Bactericidal Proteins from the Littoral Mollusk Cenchritis muricatus. Curr. Microbiol. 2012, 64, 501-505. [CrossRef] [PubMed]

17. Bradford, M.M. A rapid and sensitive method for the quantitation of microgram quantities of protein utilizing the principle of protein-dye binding. Anal. Biochem. 1976, 72, 248-254. [CrossRef]

18. LAEMMLI, U.K. Cleavage of Structural Proteins during the Assembly of the Head of Bacteriophage T4. Nature 1970, 227, 680. [CrossRef] [PubMed]

19. Bauer, A.W.; Kirby, W.M.; Sherris, J.C.; Turck, M. Antibiotic susceptibility testing by a standardized single disk method. Am. J. Clin. Pathol. 1966, 45, 493-496. [CrossRef] [PubMed]

20. Lauth, X.; Shike, H.; Burns, J.C.; Westerman, M.E.; Ostland, V.E.; Carlberg, J.M.; Van Olst, J.C.; Nizet, V.; Taylor, S.W.; Shimizu, C.; et al. Discovery and characterization of two isoforms of moronecidin, a novel antimicrobial peptide from hybrid striped bass. J. Biol. Chem. 2002, 277, 5030-5039. [CrossRef] [PubMed]

21. Sugesh, S.; Mayavu, P.; Ezhilarasan, P.; Sivashankar, P.; Arivuselvan, N. Screening of Antibacterial Activities of Marine Gastropod Hemifusus Pugilinus. Curr. Res. J. Biol. Sci. 2013, 5, 49-52.

22. Dolashka, P.; Dolashki, A.; Voelter, W.; Van Beeumen, J.; Stevanovic, S. Antimicrobial activity of peptides from the hemolymph of Helix lucorum snails. Int. J. Curr. Microbiol. Appl. Sci. 2015, 4, 1061-1071. 
23. Alcantara Santana, W.; Melo, C.; Cardoso, J.; Nely Pereira-Filho, R.; Rabelo, A.; Reis, F.; de Albuquerque, R.L.C. Assessment of Antimicrobial Activity and Healing Potential of Mucous Secretion of Achatina fulica. Int. J. Morphol. 2012, 30, 365-373. [CrossRef]

24. Gayathri, M.; Sanjeevi, S.B. Antipathogenic activity of freshwater Gastropod Pila virens (Lamarck, 1822) from Lower Grand Anaicut Reservoir, Tamilnadu. Int. J. Pharm. Life Sci. 2014, 5, 3894-3898. 